\title{
Salinity tolerance at seedling stage for rice genotypes: In vitro analysis
}

\author{
Raghad S. Mouhamad ${ }^{1 *}$, Lamiaa A. Mutlag ${ }^{1}$, Ameerah H. Atiyah ${ }^{1}$, Ibrahim B. Razaq ${ }^{1}$, Muslim \\ A. A. Abdulhussein ${ }^{2}$, Munawar Iqbal ${ }^{3}$ and Arif $\mathrm{Nazir}^{3}$
}

${ }^{1}$ Soil and Water Resources Center, Agricultural Research Directorate, Ministry of Sciences and Technology, Baghdad, Iraq.

${ }^{2}$ Agriculture College, University of Kufa, Najaf, Iraq.

${ }^{3}$ Department of Chemistry, The University of Lahore, Lahore, Pakistan.

Accepted 10 October, 2017

\begin{abstract}
Hydroponic cropping technique was utilized for evaluation of salinity tolerance of certain genotypes of rice under prevailing arid conditions of Iraq. The conditions envelop low level of characteristic issue, calcium carbonate conglomeration of soil and soils containing clear measures of gypsum, delicate to coordinate profile progression and low natural development. The seedling test is simple, rapid (4 to 6 weeks) and accurate. Furthermore, this test allows the screening of several seedlings under various experimental parameters. Therefore, the three genotypes of IRRI rice (IR71999-3R-3-2-2B-1-1, IR71829-3R-82-1-1and IR63731-1-3-3-2) and two varieties of rice (Anber and Jasmine) under salinity stress $(1.2,4,8$ and $10 \mathrm{dS} / \mathrm{M})$ were investigated. The experiment was conducted in a growth chamber under simulated arid conditions in a completely randomized distribution. Salt stress caused reductions in rice plant production (yield) reached more than $30 \%$. Dry matter weight was decreased by $24 \%$ in all varieties ofrice. Sodium $\left(\mathrm{Na}^{+}\right)$ concentration was significantly ( $p \leq 0.05$ ) higher in $\mathrm{NaCl}$-treated plants. The $\mathrm{Na}^{+} / \mathrm{K}^{+}$and $\mathrm{Na}^{+} / \mathrm{Mg}^{2+}$ ratio in IRSSTN-SS2 (IR71999-3R-3-2-2B-1-1, IR71829-3R-82-1-1) genotypes and Anber plant indicate that it is more susceptible to salinity than the rice verities. Consequently, this cultivar is more vulnerable to saltiness than the assortment Cotaxtla, which demonstrated more noteworthy resistance to this anxiety.
\end{abstract}

Keywords: Salinity, genotypes, in vitro, hydroponic, salt tolerance.

*Corresponding author. E-mail: raghad1974@yahoo.com.

\section{INTRODUCTION}

Soil salinity is a current threat to food security, especially in Iraq, where irrigation is inevitable to agricultural production (Al-Rahmani et al., 2001). More than $50 \%$ of rice soils in Iraq are now affected by salinity. Therefore, salt tolerant varieties are considered to be the most economical and effective way of increasing crop production on saline lands (Moussa, 2004). The rice plant is moderately sensitive to salinity stress, particularly during the early seedling flowering and reproductive stages (Shaibur et al., 2008). Consequently, it is suitable crops for saline soils. It is considered moderately sensitive to salinity compared to salt-tolerant halophytes. The understanding of the physiological basis of salinity tolerance was advanced by the discovery that less $\mathrm{Na}^{+}$ and more $\mathrm{K}^{+}$were absorbed to maintain a high $\mathrm{Na}$ : $\mathrm{K}$ ratio in the shoot. Improving the speed and efficiency of plant breeding programs because it is growth stage independent, unaffected by environment; no dominance effect and efficient to use in early generations (Pattanagul and Thilisakul, 2008). Under salinity stress, it is crucial for plant cells maintain the low cytotoxic $\mathrm{Na}^{+}$level while keeping the high level of $\mathrm{K}^{+}$, resulting in a high cytotoxic $\mathrm{K}^{+} / \mathrm{Na}^{+}$ratio that is preferable for vital cellular metabolisms. So the sequestration of $\mathrm{Na}^{+}$into vacuous is an efficient mechanism to reduce the cytotoxic $\mathrm{Na}^{+}$ concentration (Zolla et al., 2010). Effective strategies for glycophytes to cope with salinity stress are to keep cytosolic $\mathrm{Na}^{+}$levels low at the cellular level and to keep 
shooting $\mathrm{Na}^{+}$concentrations low at the whole plant level. In addition to these factors, acquisition and maintenance of $\mathrm{K}^{+}$were found to have a considerable impact on plant salt tolerance (Kanjoo et al., 2011). Maintenance of high cytosolic $\mathrm{K}^{+} / \mathrm{Na}^{+}$ratios, especially in shoots have been strongly suggested to be crucial for salt tolerance of glycophyte plants (Wong et al., 2013). Therefore, important questions to be addressed are whether salt tolerant cultivars of a glycoprotein or halo photos retain better systems such as superior enzyme activity, including more preferable activity/ion selectivity of transporting protein and more efficient regulations on the genes/proteins involved. The objectives of the present study to examine the relationships between $\mathrm{Na}^{+} / \mathrm{K}^{+}$, $\mathrm{Na}^{+} / \mathrm{Ca}^{2+}$ and $\mathrm{Na}^{+} / \mathrm{Mg}^{2+}$ and growth characteristics of the rice seedlings genotype under salinity stress and arid conditions.

\section{MATERIALS AND METHODS}

Five genotypes of rice (Oryx saliva L.) were hydroponically grown for testing under four levels of salinity (tap water (1.2 dS/M), well water $1(4 \mathrm{dS} / \mathrm{M})$, well water $2(8 \mathrm{dS} / \mathrm{M})$ and well water $3(12 \mathrm{dS} / \mathrm{M}))$ (Table 1) were autoclaved at $1.04 \mathrm{~kg} / \mathrm{cm}^{2}, 121^{\circ} \mathrm{C}$, for $20 \mathrm{~min}$, two Iraqi genotypes (Amber and Jasmine) and three genotypes (IR71999-3R-3-2-2B-1-1, IR71829-3R-82-1-1 and IR63731-1-3-3-2) were gated from the International Rice Research Institute (IRRI) (IRRI, 2002). Rice seeds were kept at $48^{\circ} \mathrm{C}$ for one week to break the dormancy. Seeds were surface sterilized and were dried on filter papers. Turned with some cotton and placed carefully on surface water in tissue culture tubes $(25 \times 250)$ have $50 \mathrm{ml}$ from water solution and transferred to growth chamber at $30^{\circ} \mathrm{C}$. Seventyday old seedlings were collected from three replicates and dried for $48 \mathrm{~h}$ at 55 to $60^{\circ} \mathrm{C}$ in an electric oven. The biomass dry weight of the seedlings was determined. The samples were measured dry biomass, then ground to pass 60 mesh screens. Grounded samples were acid digest for the determination of their elements content. A fine powder for digesting with perchloric acid mixture and chemical analysis. Potassium, calcium, sodium and magnesium were determined using Atomic Absorption Spectroscopy (AAS) (Page et al., 1982). Differences between individual means were identified using Turkey's range test at the $5 \%$ significance level (Little and Hill, 1978).

\section{RESULTS AND DISCUSSION}

\section{Dry matter yield}

In plant weight, highly significant $(p \leq 0.01)$ effects were found based on the source of variation in genotypes and variation of salt concentration. Similar results were obtained in dry weight in two genotypes (IR71999-3R-32-2B-1-1, IR71829-3R-82-1-1) with increased salt concentration. Under normal condition (tap water) the dry weight was the highest compared with three concentrations of salt. However, the Iraqi cultivars (Anber and Jasmine) the effect of the salt concentration was decreased with increased EC water all two cultivars decreased in response to irrigation with saline waters increased, contrary to that recorded in IR63731-1-3-3-2 genotypes were no significant difference was found compared with other genotypes (Table 2). Our experimental data indicated that rice seedlings were sensitive (IR71999-3R-3-2-2B-1-1, IR63731-1-3-3-2 and Jasmine) genotypes and tolerant genotypes (IR718293R-82-1-1 and Anber). Growth reduction was most probably due to the toxic effects of salt on enzyme activity.

\section{Effect of salt concentration of potassium}

The potassium concentration increased significantly in all

Table 1. Chemical properties of hydroponic water solution.

\begin{tabular}{lcccccccc}
\hline Water solution (Mmol/L) & $\mathbf{E c}\left(\mathbf{d S} . \mathbf{m}^{-1}\right)$ & $\mathbf{p H}$ & $\mathbf{N a}^{+}$ & $\mathbf{~ M g}^{2+}$ & $\mathbf{C a}^{2+}$ & $\mathbf{S O}_{4}{ }^{2-}$ & $\mathbf{C l}^{-}$ & SAR \\
\hline Tap water & 1.2 & 7.35 & 2.1 & 1.1 & 0.20 & 0.09 & 0.1 & 1.42 \\
Well 2 & 4 & 7.56 & 30.57 & 4.9 & 0.989 & 2.776 & 32.68 & 12.6 \\
Well 3 & 8 & 7.17 & 74 & 14.03 & 13.51 & 7.57 & 62.98 & 14.1 \\
Well 4 & 10 & 7.03 & 85.74 & 21.79 & 20.46 & 4.12 & 112.7 & 13.19 \\
\hline
\end{tabular}

Table 2. Seedlings dry matter yield of five rice genotypes with different levels of $E C(d S / M m)$.

\begin{tabular}{lcccccc}
\hline \multirow{2}{*}{ Treatment } & \multirow{2}{*}{ EC (dS/M) } & \multicolumn{5}{c}{ Genotype } \\
\cline { 3 - 7 } & & IR71829-3R-82-1-1 & IR71999-3R-3-2-2B-1-1 & Anber & Jasmine & IR63731-1-3-3-2 \\
\hline Tap water & 1.2 & $0.045^{\mathrm{A}}$ & $0.018^{\mathrm{A}}$ & $0.044^{\mathrm{A}}$ & $0.032^{\mathrm{A}}$ & $0.03^{\mathrm{A}}$ \\
Well 1 & 4 & $0.033^{\mathrm{C}}$ & $0.014^{\mathrm{C}}$ & $0.062^{\mathrm{B}}$ & $0.027^{\mathrm{B}}$ & $0.03^{\mathrm{A}}$ \\
Well 2 & 8 & $0.037^{\mathrm{B}}$ & $0.015^{\mathrm{B}}$ & $0.032^{\mathrm{C}}$ & $0.027^{\mathrm{B}}$ & $0.02^{\mathrm{B}}$ \\
Well 3 & 12 & $0.03^{\mathrm{D}}$ & $0.03^{\mathrm{D}}$ & $0.019^{\mathrm{D}}$ & $0.018^{\mathrm{C}}$ & $0.015^{\mathrm{C}}$ \\
\hline
\end{tabular}

Different letters indicate significant differences assessed by Fisher LSD test $(P \leq 0.05)$ after performing ANOVA multifactor analysis. 


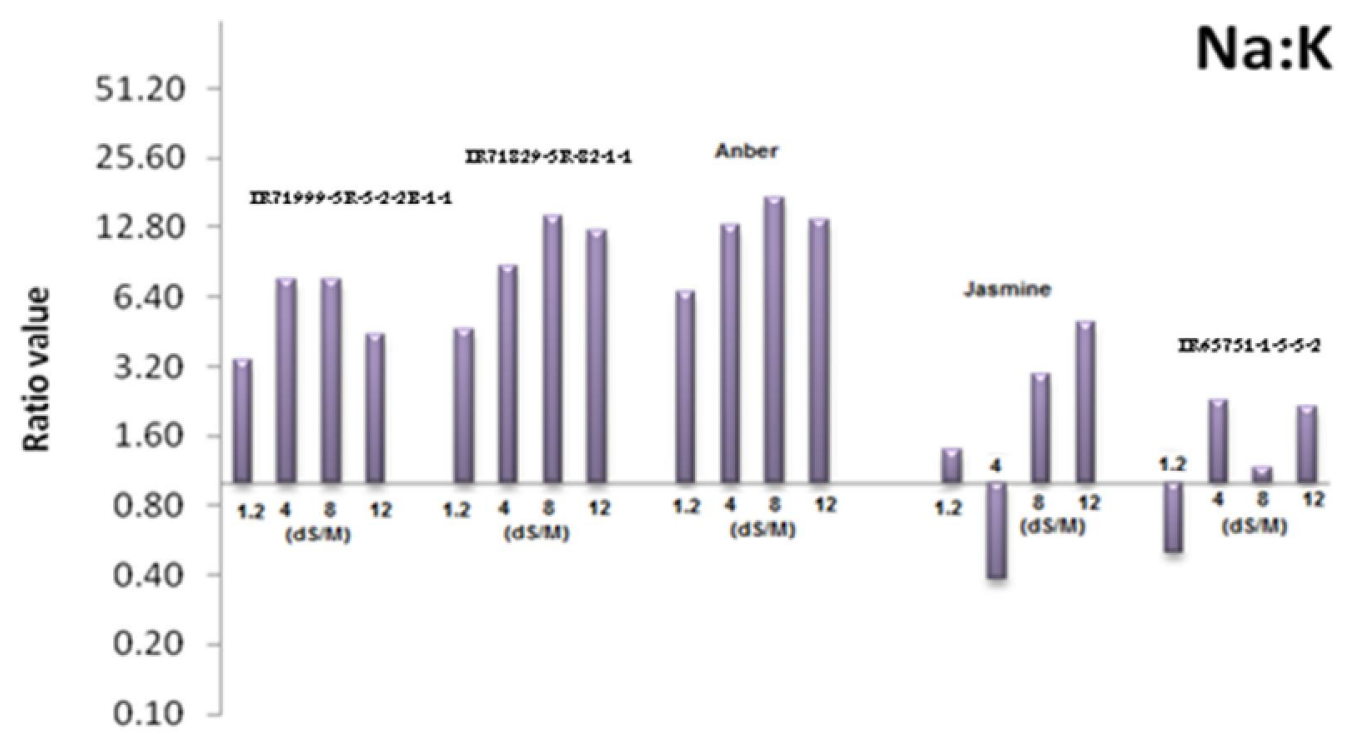

Figure $1 . \mathrm{Na} / \mathrm{K}$ ratios in rice plant under the influence of different salt concentration.

rice plants with increased $E C$ levels in the water solution (Figure 1). In IRSSTN-SS2 (IR71829-3R-82-1-1) genotype, the highest concentration was recorded in $\mathrm{Na}$ : $\mathrm{K}$ compared with another genotype IRSSTN-SS2 (IR71999-3R-3-2-2B-1-1and IR63731-1-3-3-2). The K translocation was highest in IRSSTN-SS2 (IR71829-3R82-1-1) in three types of treatment, while IRSSTN-SS2 (0.30) genotype was lowered in $\mathrm{K}$ translocation in all salt treatments. Iraqi species (Anber and Jasmine) have different behaviors under salinity conditions. The $\mathrm{K}$ content increased in various plants with increased salt stress in Anber species compared with Jasmine. $\mathrm{K}$ translocation in Anber was higher than other species and genotype that due to "luxury consumption" of $\mathrm{K}$ which is a normal phenomenon in high level of $K$ supply. These findings strongly suggest that class 1 HKT transportermediated $\mathrm{Na}^{+}$reabsorption at xylem parenchyma cell is a key component of plants to maintain a high $\mathrm{K}^{+} / \mathrm{Na}^{+}$ratio in plants, which vest in salt tolerance of the plants during salinity stress (Krishnamurthy et al., 2009).

\section{Effect of salt concentration of calcium}

Calcium concentration decreased in all rice plants with increased salt concentration in all treatments (Figure 2). The significant reductions were obtained in IRRI genotypes (IR71999-3R-3-2-2B-1-1and IR63731-1-3-3-2) compared with another genotypes (IR71829-3R-82-1-1). The Jasmine species was recorded high reduction compared with Anber species. $\mathrm{Na}^{+}$and $\mathrm{Ca}^{2+}$ both are cations, therefore, antagonist relationships between them could be possible. The most reduction of $\mathrm{Na}^{+} / \mathrm{Ca}^{2+}$ ratio was observed in IRSSTN-SS2 (IR71999-3R-3-2-2B-1-1 and IR63731-1-3-3-2) and Jasmine species compared with IRSSTN-SS2 (IR71829-3R-82-1-1) and Anber species. Calcium stabilizes cell membranes by bridging phosphate and carboxylate groups of phospholipids and preferentially protein of membrane surfaces, there can be an exchange between $\mathrm{Ca}^{2+}$ of these binding sites and other cations (Kanjoo et al., 2011).

\section{Effect of salt concentration of magnesium}

A marginal concomitant relationship was found between $\mathrm{Na}^{+}$and $\mathrm{Mg}^{2+}$. The Na:Mg ratio increased significantly in rice plant, especially in IRSSTN-SS2 (IR63731-1-3-3-2) genotype was recorded lowest $\mathrm{Na:Mg}$ ratio compared with other genotype and species. Figure 3 shows that concentration of $\mathrm{Mg}^{2+}$ in plant tissue was not affected by salt concentration. The presence of excessive amont of $\mathrm{Na}^{+}$interfers the uptake and physiological availability of $\mathrm{Mg}^{2+}$. Consequently, $\mathrm{Mg}^{2+}$ could be replaced strongly by $\mathrm{Na}^{+}$in various reactions in this experiment (Ammar et al., 2009).

\section{CONCLUSION}

The dry weight decreased significantly in rice plant under the high salt concentration (well 2 and 3) compared with well 1 and tap water, but the difference is not significantly highest so rice plants could usually be qualified as obligate glycophytes. The critical toxicity level was 8 $\mathrm{dS} / \mathrm{M}$ of salt concentration. Considering the reduced value of concentration the sensitivity of these elements can be arranged as $\mathrm{Na}^{+}>\mathrm{Mg}^{2+}>\mathrm{Ca}^{2+}$ in fine plant species. For our result it was suggested that Anber species and IRSSTN-SS2 (IR71829-3R-82-1-1) were more salinity 


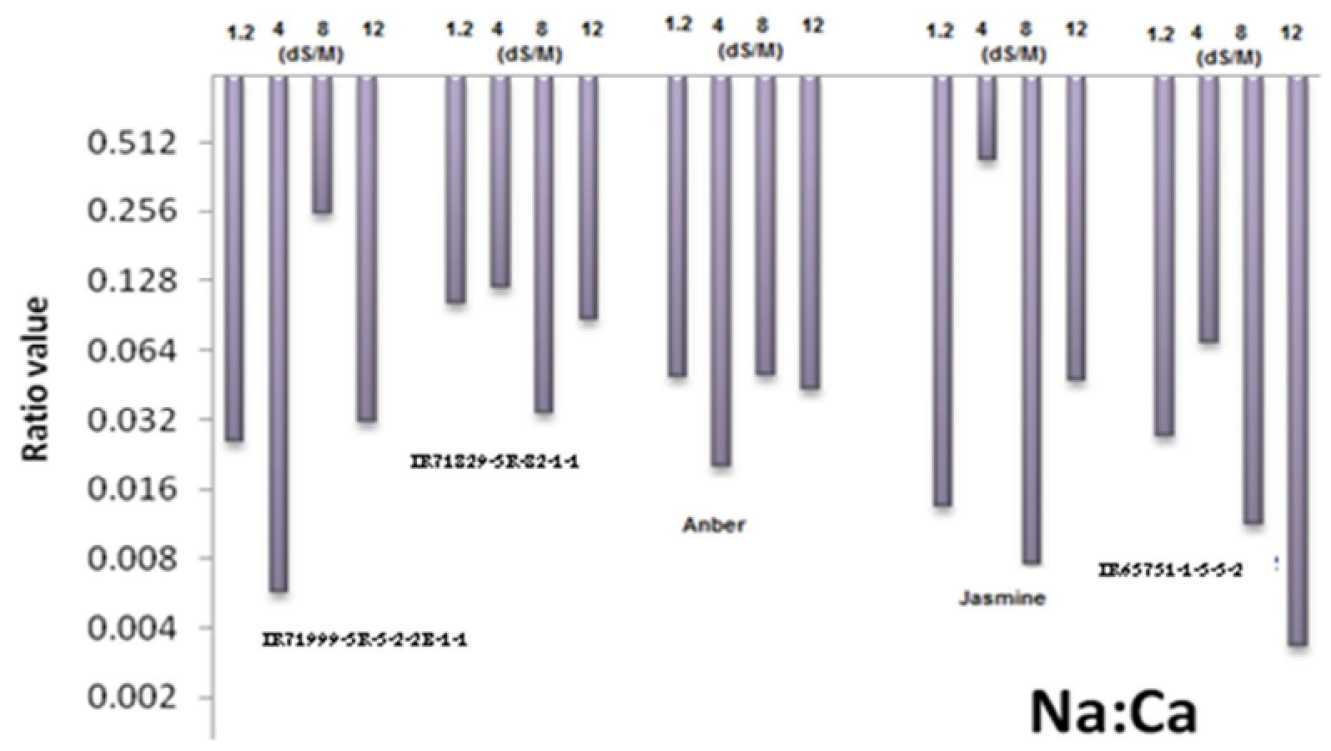

Figure 2. $\mathrm{Na}^{+} / \mathrm{Ca}^{2+}$ ratios in rice plant under the influence of different salt concentration.

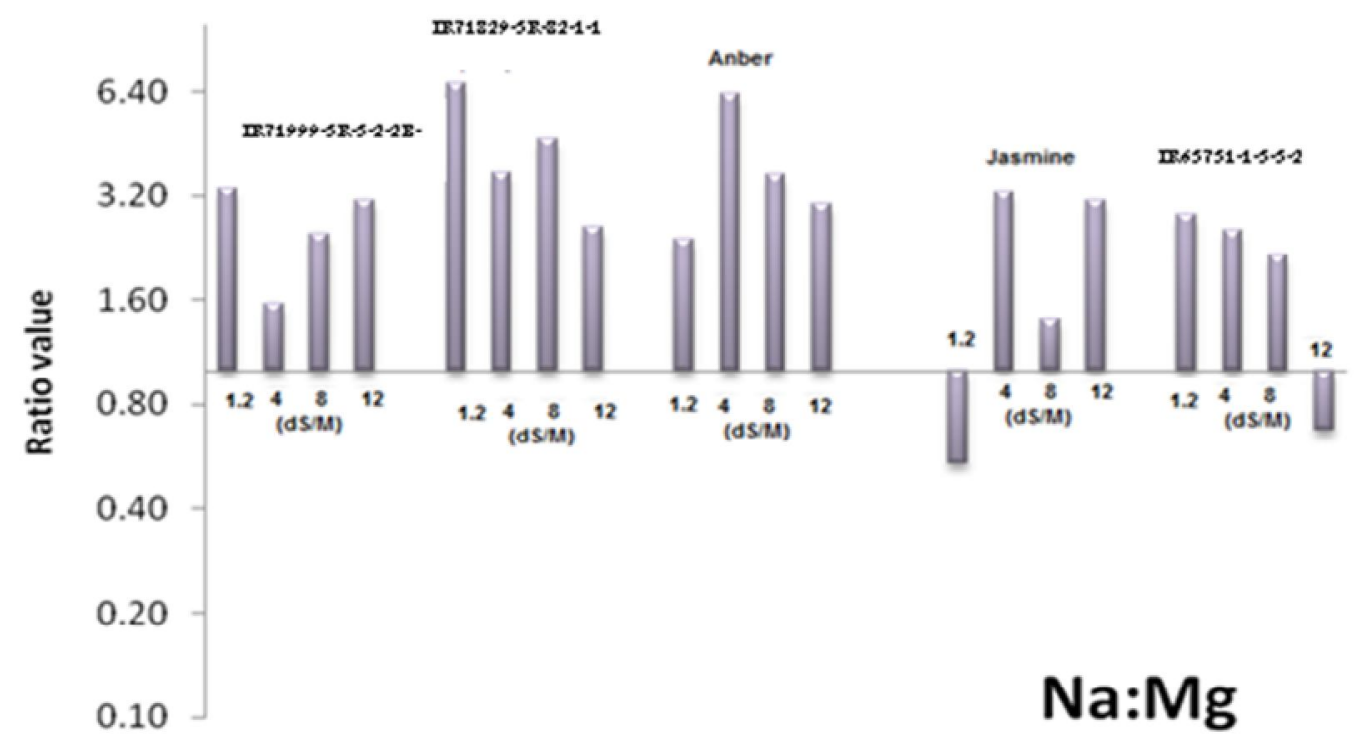

Figure 3. $\mathrm{Na}^{+} / \mathrm{Mg}^{2+}$ ratios in rice plant under different salt concentration.

tolerant species.

\section{REFERENCES}

Al-Rahmani HFK, Al-Hadithi TR, Al-Delemee HN, 2001. Calcium and salinity tolerance of barley. J D Diala, 10: 27-40.

Ammar MHM, Pandit A, Singh RK, Sameena S, Chaucan MS, Singh AK, Sharma PC, Gaikwad K, Sharma TR, Mohapatra T, Singh NK, 2009. $\mathrm{Na}^{+}, \mathrm{K}^{+}$and $\mathrm{Cl}^{-}$ion concentrations in salt tolerant Indica rice variety CSR27. J Plant Biochem Biotechnol, 18: 139-150.

IRRI, 2002. Standard Evaluation System for Rice (SES). $2^{\text {nd }}$ Edn. International Rice Research Institute, Philippines.

Kanjoo V, Jearakongman S, Punyaweaw K, Toojinda JL, 2011. Colocation of quantitative trait loci for drought and salinity tolerance in rice. Thai J Genet, 4: 126-138.

Krishnamurthy P, Ranthunge K, Franke R, Prakash HS, Schreiber L, Mathew MK, 2009. The role of root apoplastic transport barriers in salt tolerance of rice (Oryza sativa L.). Planta, 230(1): 119-134.

Little TM, Hill FJ, 1978. Agricultural Experimentation, Design and Analysis. John Wiley and Sons, New York.

Moussa HR, 2004. Amelioration of salinity-induced metabolic changes in soybean by weed exudates. Int J Agri Biol, 6(3): 499-503.

Page AL, Miller RH, Kenney DR, 1982. Method of Soil Analysis, 2nd (ed) Agron. 9, Publisher, Madiason, Wisconsin .

Pattanagul W, Thitsaksakul M, 2008. Effect of salinity stress on growth and carbohydrate metabolism in three rice (Oryza sativa L.) cultivars differing in salinity tolerance. Indian J Exp Biol, 46(10): 736742.

Shaibur MR, Shamim AHM, Kawai S, 2008. Growth response of hydroponic rice seedlings at elevated concentrations of potassium 
chloride. J Agric Rural Dev, 6: 43-53.

Wong TH, Li MW, Yao XQ, Lam HM, 2013. The GmCLC1 protein from soybean functions as a chloride ion transporter. J Plant Physiol, 170: 101-104.

Zolla G, Heimer YM, Barak S, 2010. Mild salinity stimulates a stressinduced morphogenic response in Arabidopsis thaliana roots. J Exp Bot, 61:211-224.
Citation: Mouhamad RS, Mutlag LA, Atiyah AH, Razaq IB, Abdulhussein MAA, Iqbal M, Nazir A, 2017. Salinity tolerance at seedling stage for rice genotypes: In vitro analysis. Net J Agric Sci, 5(4): 126-130. 